American Journal of Agricultural and Biological Sciences 5 (1): 56-61, 2010

ISSN 1557-4989

(C) 2010 Science Publications

\title{
Effect of Potassium Levels on Antioxidant Enzymes and Malondialdehyde Content under Drought Stress in Sunflower (Helianthus annuus L.)
}

\author{
${ }^{1}$ H. Soleimanzadeh, ${ }^{1}$ D. Habibi, ${ }^{1}$ M.R. Ardakani, ${ }^{1}$ F. Paknejad and ${ }^{2}$ F. Rejali \\ ${ }^{1}$ Department of Agronomy and Plant Breeding, College of Agriculture and Natural Resources, \\ Islamic Azad University, Karaj Branch, Karaj, Iran \\ ${ }^{2}$ Department of Soil Biology, Soil and Water Research Institute, Karaj, Iran
}

\begin{abstract}
Problem statement: Drought stress as a major adverse factor can lower leaf water potential, leading to reduced turgor and some other responses and ultimately lower crop productivity in arid and semi arid zones. Sunflower is one of the main oil seed crops in Iran, where drought stress is the most limiting factor. Drought stress tolerance requires the activation of complex metabolic activities including antioxidative pathways, especially Activated Oxygen Species (AOS) and scavenging systems within the cells which can contribute to continued growth under drought stress. Approach: To evaluate the effect of limited irrigation systems and potassium fertilizer on grain yield, antioxidant enzymes and lipid peroxidation biomarker (MDA), the crop was sown in the Research Farm of College of Agriculture, Islamic Azad University, Karaj Branch in 2009. The experimental treatments were arranged as split plots based on a Randomized Complete Block Design with three replications. The main plots were allocated to three different irrigation regimes. The irrigation regimes comprised of: Full Irrigation $\left(\mathrm{IR}_{1}\right)$, Moderate drought stress $\left(\mathrm{IR}_{5}\right)$ and Severe drought stress $\left(\mathrm{IR}_{2}\right)$. The subplots were allocated to four potassium chemical fertilizer (Potassium nitrate) consisting of $K_{1}=25, K_{2}=50, K_{3}$ $=75$ and $\mathrm{K}_{4}=100 \%$ recommended. Results: Plants under drought stress and potassium levels showed a significant increase and decrease, respectively, in SOD, CAT and GPX activity and MDA in compared to control plants. In this context, plants with higher levels of potassium showed higher resistance to drought stress conditions and higher yield and dry matter allocation to grain filling process i.e. harvest index. Results of this study suggested that drought stress leads to production of oxygen radicals, which results in increased lipid peroxidation (MDA biomarker) and oxidative stress in the plant. Conclusion: The scavenging of AOS by the scavenging system especially by SOD, CAT and GPX was done well and damage to membranes or MDA was controlled at higher levels of potassium.
\end{abstract}

Key words: Drought stress, potassium fertilizer, antioxidant enzymes, sunflower

\section{INTRODUCTION}

Adequate water and nutrient supply are important factors affecting optimal plant growth and successful crop production. Water stress is one of the severe limitations of crop growth especially in arid and semiarid regions of the world as it has a vital role in plant growth and development at all growth stages (Shamim et al., 2009).

Nitrogen, phosphorous and potassium are major elements essential for plant growth and development. To date use of chemical fertilizers has been confined mainly to the application of nitrogen and phosphorous and due attention has not been paid to the potassium. Its role is well documented in photosynthesis, increasing enzyme activity, improving synthesis of protein, carbohydrates and fats, translocation of photosynthetic, enabling their ability to resist pests and diseases. Potassium also plays key role in increasing crop yield and improving the quality of produce (Tisdale et al., 1985).

The limitation of $\mathrm{CO}_{2}$ assimilation in drought stressed plants causes the over-reduction of photosynthetic electron chain. This access of reducing power determines a redirection of photon energy into processes that favor the production of Activated Oxygen Species (AOS), mainly in the photosynthetic (Asada, 1999) and mitochondrial electron transport chains (Moller, 2001).

Corresponding Author: Hossein Soleimanzadeh, Department of Agronomy, College of Agriculture and Natural Resources, Islamic Azad University, Karaj Branch, Karaj, Iran Tel: +98 9124479969 
Drought stress invariably leads to oxidative stress in the plant cell due to higher leakage of electrons towards $\mathrm{O}_{2}$ during photosynthetic and respiratory processes leading to enhancement in activated oxygen species generation (Asada, 1999; Bartoli et al., 1999; Stepien and Klobus, 2005). The AOS such as $\mathrm{O}_{2}{ }^{-}, \mathrm{H}_{2} \mathrm{O}_{2}$ and $\mathrm{OH}$ radicals, can directly attack membrane lipids, inactive metabolic enzymes and damage the nucleic acids leading to cell death (Ouchi et al., 1990). Being toxic for cells, AOS are efficiently eliminated by nonenzymatic ( $\alpha$-tocopherol, $\beta$-carotene, phenolic compounds, ascorbate, glutathione) and enzymatic antioxidants (Noctor and Foyer, 1998; Smirnoff, 1993). The enzymatic antioxidant system is one of the protective mechanisms including superoxide dismutase (SOD: EC 1.15.1.1), which can be found in various cell compartments and it catalyses the disproportion of two $\mathrm{O}_{2}^{-}$radicals to $\mathrm{H}_{2} \mathrm{O}_{2}$ and $\mathrm{O}_{2}$ (Hegedus et al., 2001; Scandalios, 1993). $\mathrm{H}_{2} \mathrm{O}_{2}$ is eliminated by various antioxidant enzymes such as catalases (CAT: EC 1.11.1.6) (Hernandez et al., 1999; Kono and Fridovich, 1983; Scandalios, 1993) and peroxidases (POX: EC 1.11.1.7) (Gara et al., 2003; Jablonski and Anderson, 1982) which convert $\mathrm{H}_{2} \mathrm{O}_{2}$ to water. Other enzymes that are very important in the ROS scavenging system and function in the ascorbate-glutathione cycle are glutathione reductase (GR: EC 1.6.4.2), monodehydro ascorbat reductase (MDHAR: EC 1.6.5.4) and dehydroascorbate reductase (DHAR: EC 1.8.5.1) (Candan and Tarhan, 2003; Yoshimura et al., 2000). Moreover, AOS are inevitable byproducts of normal cell metabolism (Martinez et al., 2001). But under normal conditions production and destruction of AOS is well regulated in cell metabolism (Mittler, 2002). When a plant faces harsh conditions, AOS production will overcome scavenging systems and oxidative stress will burst. In these conditions, AOS attack vital biomolecules and disturb the cell metabolism and ultimately the cell causes its own death (Sakihama et al., 2002).

Malondialdehyde (MDA), a decomposition product of polyunsaturated fatty acids hydroperoxides, has been utilized very often as a suitable biomarker for lipid per oxidation (Bailly et al., 1996) which is an effect of oxidative damage. Nonetheless, lipids are not the only targets for MDA action; in fact MDA damages DNA, forming adducts to deoxyguanosine and deoxyadenosine (Marnett, 1999).
The aim of this study was to investigate the influence of drought stress and different levels of potassium on antioxidant enzymes activities and on MDA level in sunflower. We hypothesize that potassium could minimize the oxidative effect of the damage following a period of drought stress.

\section{MATERIALS AND METHODS}

The experiment was initiated in Research Farm of College of Agriculture, Islamic Azad University, Karaj Branch located in Karaj/Iran during summer 2009. Karaj is classified among the temperate climatic regions in the country with average rainfall of $256 \mathrm{~mm}$ per year. The soil physical and chemical characteristic of the experimental site is presented in Table 1 .

The experimental treatments were arranged as split plots based on a Randomized Complete Block Design with three replications. The main plots were allocated to three different irrigation regimes. The irrigation regimes comprised of:

Full irrigation (IR $)$ (control): The plots in this treatment were irrigated at weekly intervals up to the end of the growing period.

Moderate drought stress $\left(\mathbf{I R}_{\mathbf{5}}\right)$ : The plots in this treatment were irrigated at weekly intervals up to the start of the R5 stage, after this stage irrigation was cut off.

Severe drought stress $\left(\mathbf{I R}_{2}\right)$ : The plots in this treatment were irrigated at weekly intervals up to the start of the R2 stage, after this stage irrigation was cut off.

The subplots were allocated to four potassium chemical fertilizer (Potassium nitrate) consisting of $\mathrm{K}_{1}=25 \%\left(25 \mathrm{~kg} \cdot \mathrm{ha}^{-1}\right), \mathrm{K}_{2}=50 \%\left(50 \mathrm{~kg} \cdot \mathrm{ha}^{-1}\right), \mathrm{K}_{3}=$ $75 \%\left(75 \mathrm{~kg} \cdot \mathrm{ha}^{-1}\right)$ and $\mathrm{K}_{4}=100 \%$ recommended (100 kg.ha $\left.{ }^{-1}\right)$.

Seed bed preparation was done in early autumn. The cultivation rows were $60 \mathrm{~cm}$ apart in each plot (at 10 plants $\mathrm{m}^{2}$ density). Weeds were removed by hand and plots were irrigated as required through the growing season.

Table 1: Soil physical and chemical properties of experimental area

\begin{tabular}{|c|c|c|c|c|c|c|c|c|c|c|}
\hline $\begin{array}{l}\text { Depth } \\
\text { (cm) }\end{array}$ & $\begin{array}{l}\text { Sand } \\
(\%)\end{array}$ & $\begin{array}{l}\text { Silt } \\
(\%)\end{array}$ & $\begin{array}{l}\text { Clay } \\
(\%)\end{array}$ & $\begin{array}{l}\text { Soil } \\
\text { texture }\end{array}$ & $\mathrm{PH}$ & $\begin{array}{l}\text { E.C } \\
\left(\mathrm{ds} \mathrm{m}^{-1}\right)\end{array}$ & $\begin{array}{l}\text { Organic } \\
\text { carbon }(\%)\end{array}$ & $\begin{array}{l}\text { Total N } \\
(\%)\end{array}$ & $\begin{array}{l}\text { Available } \\
\mathrm{P}(\mathrm{ppm})\end{array}$ & $\begin{array}{l}\text { Available } \\
\mathrm{K} \text { (ppm) }\end{array}$ \\
\hline $0-30$ & 61 & 20 & 19 & Sand loam & 7.4 & 3.64 & 0.49 & 0.05 & 7.8 & 192 \\
\hline Optimum & & & & loam & $6.5-7.5$ & $2.00<$ & $>1.00$ & $1.0>$ & $10-15$ & $200-300$ \\
\hline
\end{tabular}


Sampling: After drought stress treatment, three leaves of each plant were removed. The samples were washed and then frozen in liquid $\mathrm{N} 2$ and then stored at $-80^{\circ} \mathrm{C}$ pending biochemical analysis.

Preparation of extracts: Leaf sample was homogenized in a mortar and pestle with $3 \mathrm{~mL}$ ice-cold extraction buffer ( $25 \mathrm{mM}$ sodium phosphate, $\mathrm{pH}$ 7.8). The homogenate was centrifuged at $18000 \mathrm{~g}$ for $30 \mathrm{~min}$ at $48^{\circ} \mathrm{C}$ and then supernatant was filtered through paper. The supernatant fraction was used as a crude extract for the assay of enzyme activity. All operations were carried out at $48^{\circ} \mathrm{C}$.

Assay of antioxidant enzymes: Catalase activity was estimated by the method of Cakmak and Horst (1991). The reaction mixture contained 100 crude enzyme extract, $500 \mu \mathrm{L} 10 \mathrm{mM} \mathrm{H} 2 \mathrm{O} 2$ and $1400 \mu \mathrm{L} 25 \mathrm{mM}$ sodium phosphate buffer. The decrease in the absorbance at $240 \mathrm{~nm}$ was recorded for $1 \mathrm{~min}$ by spectrophotometer, model Cintra 6 GBC (GBC Scientific Equipment, Dandenong, Victoria, Australia). CAT activity of the extract was expressed as CAT units per milligram of PROT. Superoxide dismutase activity was determined with the reaction mixture contained $100 \mu \mathrm{L} 1 \mu \mathrm{M}$ riboflavin, $100 \mu \mathrm{L} 12 \mathrm{mM} \mathrm{L}$-methionine, $100 \mu \mathrm{L} 0.1 \mathrm{mM}$ EDTA (pH 7.8), $100 \mu \mathrm{L} 50 \mathrm{mM} \mathrm{Na} 2$ $\mathrm{CO} 3(\mathrm{pH} 10.2)$ and $100 \mu \mathrm{L} \quad 75 \mu \mathrm{M}$ Nitroblue Tetrazolium (NBT) in $2300 \mu \mathrm{L} 25 \mu \mathrm{mM}$ sodium phosphate buffer ( $\mathrm{pH}$ 6.8), $200 \mu \mathrm{L}$ crude enzyme extract in a final volume of $3 \mathrm{~mL}$. SOD activity was assayed by measuring the ability of the enzyme extract to inhibit the photochemical reduction of NBT glass test tubes containing the mixture were illuminated with a fluorescent lamp $(120 \mathrm{~W})$; identical tubes that were not illuminated served as blanks. After illumination for $15 \mathrm{~min}$, the absorbance was measured at $560 \mathrm{~nm}$. One unit of SOD was defined as the amount of enzyme activity that was able to inhibit by $50 \%$ the photo reduction of NBT to blue Formosan. The SOD activity of the extract was expressed as SOD units per milligram of PROT. Peroxides activity was determined by the oxidation of guaiacol in the presence of $\mathrm{H}_{2} \mathrm{O}_{2}$. The increase in absorbance was recorded at $470 \mathrm{~nm}$ (Hernandez et al., 2000). The reaction mixture contained $100 \mu \mathrm{L}$ crude enzyme, $500 \mu \mathrm{L} \mathrm{H}_{2} \mathrm{O}_{2} 5 \mathrm{mM}, 500 \mu \mathrm{L}$ guaiacol $28 \mathrm{mM}$ and $1900 \mu \mathrm{L}$ potassium phosphate buffer $60 \mathrm{mM}(\mathrm{pH} 6.1)$. POX activity of the extract was expressed as POX units per mg.

Malondialdehyde (MDA) was measured by colorimetric method (Stewart and Bewley, 1980). About $0.5 \mathrm{~g}$ of leaf samples were homogenized in $5 \mathrm{ml}$ of distilled water. An equal volume of $0.5 \%$ Thiobarbituric Acid (TBA) in 20\% trichloroacetic acid solution was added and the sample incubated at $95^{\circ} \mathrm{C}$ for $30 \mathrm{~min}$. The reaction stopped by putting the reaction tubes in the ice bath. The samples then centrifuged at $10000 \times \mathrm{g}$ for $30 \mathrm{~min}$. The supernatant removed, absorption read at $532 \mathrm{~nm}$ and the amount of nonspecific absorption at $600 \mathrm{~nm}$ read and subtracted from this value. The amount of MDA present calculated from the extinction coefficient of $155 \mathrm{mM}^{-1} \mathrm{~cm}^{-1}$.

Enzyme activity and MDA content of samples were recorded with duplication.

Statistical analysis: Data were subjected to analysis of variance. Mean comparison was conducted using the Duncan's Multiple Range Test (DMRT) at 5\% level of probability.

\section{RESULTS}

The statistical analysis of data showed that there was a significant difference in grain yield production and harvest index due to different irrigation regimes (Table 2). The highest grain yield of $3.477 \mathrm{t} / \mathrm{ha}$ was obtained from control plots while the lowest grain yield of $1.449 \mathrm{t} / \mathrm{ha}$ was produced in cut off irrigation in $\mathrm{R}_{2}$ stage. Alza and Fernandez-Martinez (1997) explained that the significant difference in grain sunflower yield at different limited irrigation regimes was due to different irrigation intervals. The severe reduction of grain yield in irrigation regimes of $I_{5}$ and $I_{2}$ indicated the plant sensitivity to drought stress at different phonological stages. grain production decreased about 36 and $59 \%$ in $\mathrm{IR}_{5}$ and $\mathrm{IR}_{2}$ treatments compared to control, respectively.

There was significant difference among potassium fertilizer levels on harvest index (not grain yield).

Plants under drought stress showed significant increase in SOD, CAT, GPX activity and MDA in leaves compared to control plants. With increasing of potassium levels at all irrigation regimes, plants decreased the antioxidant enzymes activity and MDA biomarker. In this context, plants with higher levels of antioxidants, either constitutive or induced, have been reported to possess SOD eater resistance to these stress conditions and higher yield and dry matter allocation to filling process i.e., harvest index (Table 3). $\mathrm{H}_{2} \mathrm{O}_{2}$ can be removed using the ascorbateglutathion cycle ascorbic acid (ASA)-GSH cycle which APX and SOD are key enzymes in this cycle (Pasternak et al., 2005). In this study, drought stress and low potassium levels led to a significant increase in the GPX compared to the respective control (Table 3). 
Am. J. Agri. \& Biol. Sci., 5 (1): 56-61, 2010

Table 2: Analysis of variance for experimental traits

\begin{tabular}{|c|c|c|c|c|c|c|c|}
\hline \multicolumn{8}{|c|}{ MS } \\
\hline Treatment & Df & Grain yield & Harvest index & SOD & CAT & GPX & MDA \\
\hline$\overline{\mathrm{R}}$ & 2 & $0.430^{\text {ns }}$ & $21.000^{\mathrm{ns}}$ & $14117.444^{\mathrm{ns}}$ & $72.694^{\text {ns }}$ & $133.027^{\mathrm{ns}}$ & $2.043^{\mathrm{ns}}$ \\
\hline Drought levels (D) & 2 & $12.504^{* *}$ & $212.250^{* * *}$ & $3543393.861^{* *}$ & $15087.861^{* *}$ & $21114.111^{* *}$ & $8225.807^{* *}$ \\
\hline Error & 4 & 0.120 & 1.875 & 13470.860 & 15.819 & 103.194 & 4.976 \\
\hline Potassium levels (K) & 3 & $0.421^{\mathrm{ns}}$ & $44.851^{*}$ & $623354.324^{* *}$ & $3212.666^{* *}$ & $4546.472^{* *}$ & $2588.804^{* *}$ \\
\hline $\mathrm{D} * \mathrm{~K}$ & 6 & $0.011^{\mathrm{ns}}$ & $8.101^{\mathrm{ns}}$ & $71976.046^{* *}$ & $420.638^{* *}$ & $751.333^{* *}$ & $573.992^{* *}$ \\
\hline Error & 18 & 0.156 & 9.990 & 1486.056 & 49.925 & 51.768 & 10.959 \\
\hline $\mathrm{CV}$ & & 16.500 & 10.700 & 7.900 & 4.800 & 2.800 & 3.700 \\
\hline
\end{tabular}

ns, * and **: Non significant and significant at the 5 and $1 \%$ levels of probability, respectively

Table 3: Yield, harvest index, antioxidant enzymes and MDA affected by different irrigation regimes and potassium fertilizer levels

\begin{tabular}{|c|c|c|c|c|c|c|c|}
\hline $\begin{array}{l}\text { Irrigation } \\
\text { regimes }\end{array}$ & $\begin{array}{l}\text { Potassium } \\
\text { levels }\end{array}$ & $\begin{array}{l}\text { Grain yield } \\
\left(\text { t.ha }^{-1}\right)\end{array}$ & $\begin{array}{l}\text { Harvest } \\
\text { index (\%) }\end{array}$ & $\begin{array}{l}\text { SOD } \\
\left(\mathrm{u} \mathrm{mg}^{-1} \text { protein) }\right.\end{array}$ & $\begin{array}{l}\text { CAT } \\
\left(\mathrm{u} \mathrm{mg}^{-1} \text { protein) }\right.\end{array}$ & $\begin{array}{l}\text { GPX } \\
\left(\mathrm{u} \mathrm{mg}^{-1} \text { protein) }\right.\end{array}$ & $\begin{array}{l}\text { MDA } \\
\text { (nmol mg-1 protein) }\end{array}$ \\
\hline \multirow[t]{4}{*}{$\overline{\mathrm{IR} 1}$} & K1 & $3.171^{\mathrm{a}}$ & $33^{\mathrm{ab}}$ & $1625.0^{\mathrm{e}}$ & $117.3^{\mathrm{d}}$ & $223.0^{\mathrm{d}}$ & $99.1^{\mathrm{d}}$ \\
\hline & $\mathrm{K} 2$ & $3.460^{\mathrm{a}}$ & $34^{\mathrm{a}}$ & $1605.3^{\mathrm{e}}$ & $117.0^{\mathrm{d}}$ & $222.0^{\mathrm{d}}$ & $62.3^{\mathrm{f}}$ \\
\hline & K3 & $3.531^{\mathrm{a}}$ & $34^{\mathrm{a}}$ & $1201.7^{\mathrm{f}}$ & $96.3^{\mathrm{e}}$ & $205.3^{\mathrm{e}}$ & $43.3^{\mathrm{g}}$ \\
\hline & K4 & $3.747^{\mathrm{a}}$ & $35^{\mathrm{a}}$ & $1213.3^{\mathrm{f}}$ & $97.3^{\mathrm{e}}$ & $208.0^{\mathrm{e}}$ & $44.1^{\mathrm{g}}$ \\
\hline \multirow[t]{4}{*}{ IR5 } & $\mathrm{K} 1$ & $1.934^{\text {bcde }}$ & $23^{\mathrm{e}}$ & $2423.3^{\mathrm{b}}$ & $165.3^{\mathrm{b}}$ & $293.0^{\mathrm{b}}$ & $112.6^{\mathrm{b}}$ \\
\hline & K2 & $2.259^{\text {bcd }}$ & $26^{\mathrm{de}}$ & $2129.3^{\mathrm{d}}$ & $142.7^{\mathrm{c}}$ & $250.3^{c}$ & $97.2^{\text {de }}$ \\
\hline & K3 & $2.376^{\mathrm{bc}}$ & $27^{\text {cde }}$ & $2261.7^{\mathrm{c}}$ & $143.7^{\mathrm{c}}$ & $247.7^{\mathrm{c}}$ & $93.5^{\mathrm{e}}$ \\
\hline & K4 & $2.460^{\mathrm{b}}$ & $28^{\text {bcde }}$ & $1605.0^{\mathrm{e}}$ & $119.3^{\mathrm{d}}$ & $213.3^{\mathrm{de}}$ & $60.1^{\mathrm{f}}$ \\
\hline \multirow[t]{4}{*}{ IR2 } & K1 & $1.249^{\mathrm{e}}$ & $24^{\mathrm{de}}$ & $2675.7^{\mathrm{a}}$ & $202.0^{\mathrm{a}}$ & $322.3^{\mathrm{a}}$ & $118.9^{\mathrm{a}}$ \\
\hline & K2 & $1.324^{\mathrm{e}}$ & $25^{\mathrm{de}}$ & $2697.0^{\mathrm{a}}$ & $201.0^{\mathrm{a}}$ & $319.3^{\mathrm{a}}$ & $124.0^{\mathrm{a}}$ \\
\hline & $\mathrm{K} 3$ & $1.556^{\mathrm{de}}$ & $30^{\text {abcd }}$ & $2450.0^{\mathrm{b}}$ & $167.7^{\mathrm{b}}$ & $292.3^{\mathrm{b}}$ & $105.1^{\mathrm{c}}$ \\
\hline & K4 & $1.669^{\text {cde }}$ & $32^{\mathrm{abc}}$ & $2108.3^{\mathrm{d}}$ & $141.0^{\mathrm{c}}$ & $259.0^{\mathrm{c}}$ & $109.8^{\mathrm{bc}}$ \\
\hline
\end{tabular}

For a given means within each column of each section followed by the same letter are not significantly different $(\mathrm{p}<0.05)$

The diverse responses of GPX, CAT and SOD enzyme activities in the plants subjected to drought conditions suggest that oxidative stress is an important of drought stress (Turk et al., 1980). These results are in agreement with those of Tohidi Moghadam et al. (2009) who have propounded that GPX, SOD and CAT action suggests that the more active ascorbateglutathione cycle may be related to the development of relatively higher drought tolerance in canola. These results may point out that low potassium level provokes antioxidant enzyme responses (Table 3 ).

MDA content increased and decreased considerably upon drought treatments and higher potassium levels, respectively. Our results suggest that drought stress directly or indirectly leads to production of oxygen radicals, which results in increased lipid peroxidation and oxidative stress in the plant. Drought stress may also lead to stomata closure, which reduces $\mathrm{CO}_{2}$ availability in the leaves and inhibits carbon fixation. This exposes the chloroplast to excessive excitation energy, which in turn could increase the generation of free radicals and induce oxidative stress (Johnson et al., 2003). Results of this study showed that potassium decreased the activity of antioxidant enzymes and MDA content maybe by elimination of free radicals.

\section{DISCUSSION}

The result indicated that there was a negative relationship between SOD, CAT and GPX activity and lipid peroxidation or MDA content. In this study, SOD activity increased with increasing drought stress and decreased with increasing potassium levels. When SOD activity was high, AOS, especially superoxide radical, scavenging was done properly and thus, damage to membranes and oxidative stress decreased, leading to the increase of tolerance to oxidative stress. Drought stress increased the superoxide level in cells. If this radical is not scavenged by SOD, it disturbs vital bimolecular (Mittler, 2002). Moreover, it inactivates antioxidant enzymes which are very important for $\mathrm{H}_{2} \mathrm{O}_{2}$ scavenging such as catalases (Kono and Fridovich, 1983) and peroxides (Esfandiari et al., 2007). Candan and Tarhan (2003); Martinez et al. (2001); Scandalios (1993); Sen Gupta et al. (1993); Zhao et al. (2006) and Esfandiari et al. (2007) had similar findings and expressed that the increase in SOD activity and decrease in oxidative damage were closely related.

A-biotic stress, such as drought stress cause molecular damage to plant cells either directly or indirectly through the formation of AOS. In the present study, the plants exposed to drought showed a significant increase in CAT and GPX activity and a significant decrease in CAT and GPX activity with 
increase of potassium levels. The enzymes assayed are scavengers of free radical species. Hydrogen peroxide is converted to oxygen and water by CAT and GPX, which use ascorbate as the hydrogen donor. In conclusion, the results of the present study clearly showed that there was scavenging enzymes in sunflower under different drought stress and high potassium levels.

MDA is regarded as a biomarker for evaluation of lipid peroxidation or damage to plasmalemma and organelle membranes that increases with environmental stresses. Lipid per oxidation is linked to the activity of antioxidant enzymes e.g., with the increase of SOD, APX, GPX and CAT. Oxidative stress tolerance is enhanced and MDA is decreased. In this study, the amount of MDA in plants increased with the increase of drought stress, but it was decreased with increasing of potassium levels. According to this experiment data, the increase in the concentration of MDA in higher drought stress and lower potassium levels due to the low activity of SOD and GPX or CAT was a critical factor for the damage of oxidative stress.

\section{CONCLUSION}

The sum of the above results showed that AOS plays a key role in the functionality of sunflower plants subjected to drought stress conditions. For successful scavenging of AOS by a scavenging system, some antioxidant enzymes must cooperate with each other. Moreover, there was a positive relationship between antioxidant enzymes activity such as SOD, CAT and GPX and MDA. The repairing of damage due to oxidative stress, generated by drought stress, was associated with a different antioxidant response in plants grown in optimum potassium conditions.

\section{REFERENCES}

Alza, J.O. and J.M. Fernandez-Martinez, 1997. Genetic analysis of yield and related traits in sunflower in dryland and irrigated environments. Euphytica, 95: 243-251. http://cat.inist.fr/?aModele $=$ afficheN\&cpsidt $=2840834$

Asada, K., 1999. The water cycle in chloroplasts scavenging of active oxygens and dissipation of excess photons. Annu. Rev. Plant Physiol. Plant Mol. Biol., 50: 601-639. PMID: 15012221

Bailly, C., A. Benamar, F. Corbineau and D. Dome, 1996. Changes in malondialdehyde content and in superoxide dismutase, catalase and glutathione reductase activities in sunflower seed as related to deterioration during accelerated aging. Physiol. Plant., 97: 104-110. DOI: 10.1111/j.13993054.1996.tb00485.x
Bartoli, C.G., M. Simontacchi, E. Tambussi, J. Beltrano and E. Montald et al., 1999. Drought and wateringdependent oxidative stress: Effect on antioxidant content in Tritium aestivum L. leaves. J. Exp. Bot., 50: 375-383.

http://jxb.oxfordjournals.org/cgi/content/abstract/5 0/332/373

Cakmak, I. and W. Horst, 1991. Effect of aluminum on lipid peroxidation, superoxide dismutase, catalase and peroxidase activities in root tip of soybean (glycine max L.). Plant Physiol., 83: 463-468. DOI: 10.1111/j.1399- 3054.1991.tb00121.x

Candan, N. and L. Tarhan, 2003. The correlation between antioxidant enzyme activities and lipid peroxidation levels in menthe pulegium organs grown in $\mathrm{Ca}^{2+}, \mathrm{Mg}^{2+}, \mathrm{Cu}^{2+}, \mathrm{Zn}^{2+}$ and $\mathrm{Mn}^{2+}$ stress conditions. Plant Sci. 163: 769-779. http://www.elsevier.com/wps/find/journaldescripti on.cws_home/506030

Esfandiari, E., M.R., Shakiba, S. Mahboob, H. Alyari and M. Toorchi. 2007. Water stress, antioxidant enzyme activity and lipid peroxidation in wheat seedling. J. Food Agric. Environ., 5: 149- 153. http://www.world.food.net/scientficjournal/2007/is sue1/abstracts/abstract31.php

Gara, L.D., M.C. Pinto and F. Tommasi, 2003. The antioxidant systems vis-á-vis reactive oxygen species during plant-pathogen interaction. Plant Physiol. Biochim., 41: 863-870. http://cat.inist.fr/?aModele $=$ afficheN\&cpsidt $=1516$ 1256

Hegedus, A., S. Erdei and G. Horvath, 2001. Comparative studies of $\mathrm{H} 2 \mathrm{O} 2$ detoxifying enzymes in green and greening barley seedlings under cadmium stress. Plant Sci., 160: 1085-1093. DOI: 10.1016/S0168-9452(01)00330-2

Hernandez, J.A., A. Campillo, A. Jimenez, J.J. Alarcon and F. Sevilla, 1999. Response of antioxidant systems and leaf water relations to $\mathrm{NaCl}$ stress in pea plants. New Phytol., 141: 241-251. http://cat.inist.fr/?aModele $=$ afficheN\&cpsidt=1711035

Hernandez, J.A., A. Jimenez, P. Mullineaux and F. Sevilla, 2000. Tolerance of pea (Pisum sativum L.) to long-term salt stress is associated with induction of antioxidant defenses. Plant Cell Environ., 23: 853-862. http://cat.inist.fr/?aModele=afficheN\&cpsidt=1460306

Jablonski, P.P. and J.W. Anderson, 1982. Lightdependent reduction of hydrogen peroxide by ruptured pea chloroplasts. Plant Physiol., 69: 1407-1403. http://www.plantphysiol.org/cgi/content/abstract/1 $69 / 3 / 1407$ 
Johnson, S.M., S.J. Doherty and R.R.D. Croy, 2003. Biphasic superoxide generation in potato tubers: A self amplifying response to stress. Plant Physiol., 13: $1440-1449$. http://www.plantphysiol.org/cgi/content/abstract/1 $31 / 3 / 1440$

Kono, Y. and I. Fridovich, 1983. Inhibition and reactivation of Mn-Catalase. J. Biol. Chemistry, 258: 13646-13468. http://scialert.net/pdfs/pjbs/2008/1916-1922

Marnett, L.J., 1999. Lipid peroxidation-DNA damage by malondialdehyde. Mutat. Res., 424: 83-95. DOI: 10.1016/S0027-5107(99)00010-X

Martinez, C.A., M.E. Loureiro, M.A. Oliva and M. Maestri, 2001. Differential responses of superoxide dismutase in freezing resistant solanum tuberosum subjected to oxidative and water stress. Plant Sci., 160: 505-515. DOI: $10.1016 / \mathrm{S} 0168-$ 9452(00)00418-0

Mittler, R., 2002. Oxidative stress, antioxidants and stress tolerance. Trends Plant Sci., 7: 405-410. PMID: 12234732

Moller, I.M., 2001. Plant mitochondria and oxidative stress: Electron transport, NADPH turnover and metabolism of reactive oxygen species. Annu. Rev. Plant Physiol. Plant Mol. Biol., 52: 561-591. DOI: 10.1146/annurev.arplant.52.1.561

Noctor, G. and C.H. Foyer, 1998. Ascorbate and glutathione: Keeping active oxygen under control. Annu. Rev. Plant Physiol. Plant Mol. Biol., 49: 249-279. PMID: 15012235

Ouchi, S., A. Nishikawa and E. Kameda, 1990. Soilimproving effect of a super-waterabsorbentpolymer II. Evaporation, leaching of salts and growth of vegetables. Jap. J. Soil Sci. Plant Nutr., 61: 606-613. http://www.fao.org/agris/search/display.do?f=./199 4/v2007/JP9306919.xml;JP9306919

Pasternak, T., V. Rudas, G. Potters and M.A.K. Jansen, 2005. Morphogenic effects of abiotic stress: Reorientation of growth in arabidopsis thaliana seedlings. Environ. Exp. Bot., 53: 299-314. http://cat.inist.fr/?aModele $=$ afficheN\&cpsidt $=1671$ 0563

Sakihama, Y., M.F. Cohen, S.C. Grace and H. Yamasaki, 2002. Plant phenolic antioxidant and prooxidant activities: Phenolics-induced oxidative damage mediated by metals in plants. Toxicology, 177: 67-80. DOI: 10.1016/S0300483X(02)00196-8

Scandalios, J.G., 1993. Oxygen stress and superoxide dismutase. Plant Physiol., 101: 712-726. http://www.pubmedcentral.nih.gov/articlerender.fc gi? artid=158641
Sen Gupta, A., R.P. Webb, A.S. Holaday and R.D. Allen, 1993. Overexpression of superoxide dismutase protects plants from oxidative stress. Plant Physiol., 103: 1067-1073. http://www.plantphysiol.org/cgi/content/abstract/1 03/4/1067

Shamim, A., A. Rashid, Y.A. Muhammad, M. Ashraf and A.W. Ejaz, 2009. Sunflower (Helianthus annuus L.) response to drought stress at germination and seedling growth stages. Pak. J. Bot., 41: 647-654. http://www.pakbs.org/pjbot/abstracts/41(2)/19.html Smirnoff, N., 1993. The role of active oxygen in the response to water deficit and desiccation. New Phytol., 125: 27-58. DOI: 10.1111/j.14698137.1993.tb03863.x

Stepien, P. and G. Klobus, 2005. Antioxidant defense in the leaves of C3 and C4 plants under salinity stress. Physiol. Plant, 125: 31-40. http://cat.inist.fr/?aModele $=$ afficheN\&cpsidt $=1706$ 3393

Stewart, R.R.C. and J.D. Bewley, 1980. Lipid peroxidation associated aging of soybean axes. Plant Physiol., 65: 245-248. http://www.plantphysiol.org/cgi/content/abstract/6 $5 / 2 / 245$

Tisdale, S.L., W.L. Nelson and J.D. Beaton, 1985. Soil Fertility and Fertilizers. Macmillan Pub. Co. New York. pp: 249-91. ISBN: 964-03-3985-7

Tohidi-Moghadam, H.R., A.H. Shirani-Rad, G. NourMohammadi, D. Habibi and M. Mashhadi-AkbarBoojar, 2009. Effect of super absorbent application on antioxidant enzyme activities in canola (Brassica napus L.) cultivars under water stress conditions. Am. J. Agric. Biol. Sci., 3: 215-223.

Turk, K.J., A.E. Hall and G.W. Asbell, 1980. Drought adaption of cowpea I. influence of drought on seed yield. Agron. J., 72: 413-420. http://agron.scijournals.org/cgi/content/abstract/72/ $3 / 413$

Yoshimura, K., Y. Yabute, T. Ishikawa and S. Shigeoka, 2000. Expression of spinach ascorbate peroxidase isoenzymes in response to oxidative stresses. Plant Physiol., 123: 223-233. http://www.jstor.org/pss/4279251

Zhao, F., S. Guo, H. Zhang and Y. Zhao, 2006. Expression of yeast SOD2 in transgenic rice results in increased salt tolerance. Plant Sci., 170: 216-224. DOI: 10.1016/j.plantsci.2005.08.017 